\title{
Mechanical Properties of Femoral Diaphysis and Femoral Neck of Female Rats Chronically Exposed to Various Levels of Cadmium
}

\author{
M. M. Brzóska · K. Majewska • \\ J. Moniuszko-Jakoniuk
}

Published online: 14 February 2007

(C) Springer Science+Business Media, Inc. 2007

\section{Erratum to: Calcif Tissue Int (2005) 76:287-298 DOI 10.1007/s00223-004-0089-x}

Due to a transmission error in the production of the above article, the wrong version of Fig. 2 was published in the online pdf and print versions. The online HTML version is correct. The correct Fig. 2 appears below:

In addition, the following corrections also were not converted from the HTML version to the print and pdf versions:

Page 287: The city for affiliation 1 should be Bialystok (not Biaystok)

Page 288: In Experimental Design, line 4 should read " $\mathrm{CdCl}_{2} \cdot 21 / 2 \mathrm{H}_{2} \mathrm{O}$ POCh" (the $\mathrm{H}_{2} \mathrm{O}$ is missing)

Table 1: column 1, last line of body of table, it should read "MRWT" (not MRWT ${ }^{8}$ )

Table 4: column 3, line 6 of body of table, it should read "0.383" $\left(\right.$ not $\left.0.383^{\dagger}\right)$

The online version of the original article can be found under doi:10.1007/s00223-004-0089-x.

\section{M. Brzóska ( $\bowtie) \cdot J$. Moniuszko-Jakoniuk}

Department of Toxicology, Medical University of Bialystok,

Mickiewicza 2C, 15-222 Bialystok, Poland

e-mail: mmbr@poczta.onet.pl

\section{K. Majewska}

Chair of Food Plant Chemistry and Processing, Faculty of Food

Science, University of Warmia and Mazury in Olsztyn,

Plac Cieszyński 1, 10-957 Olsztyn, Poland
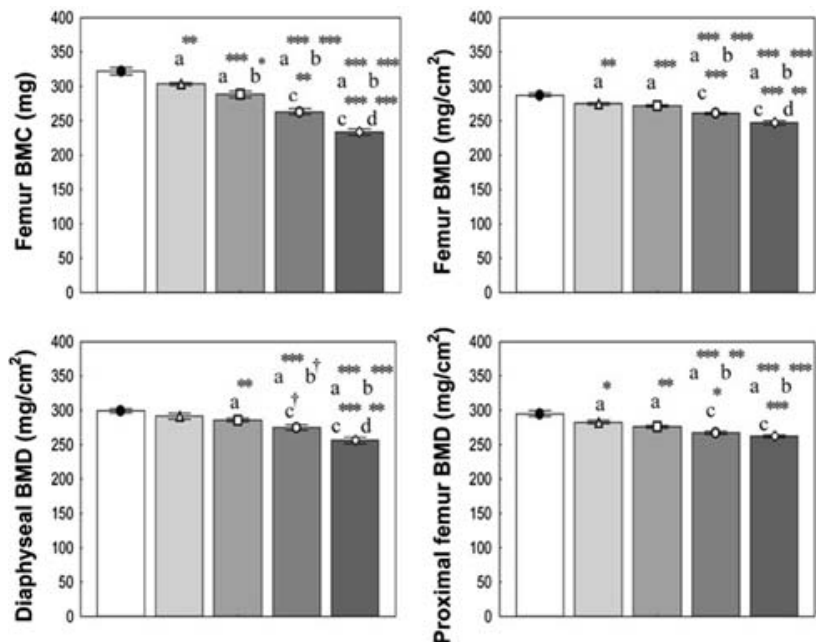

- Control

$\triangle 1 \mathrm{mg} \mathrm{Cd} / \mathrm{l}$

ㄷ $5 \mathrm{mg} \mathrm{Cd} / \mathrm{l}$

○ $50 \mathrm{mg} \mathrm{Cd} / \mathrm{l}$

$\diamond 100 \mathrm{mg} \mathrm{Cd} / \mathrm{l}$

Fig. 2 Effects of chronic (12-month) exposure to cadmium (Cd) on the mineral status of the femur. Bone mineral content (BMC) and bone mineral density (BMD) of whole femur and BMD at the middiaphysis and proximal region of the femur consisting of the head and neck of the bone were measured by dual energy X-ray absorptiometry (DEXA). Data are mean \pm SEM of 10 animals. Statistically significant difference (ANOVA + Kruskal-Wallis ranks test) from: ${ }^{\mathrm{a}}$ control, ${ }^{\mathrm{b}} 1 \mathrm{mg} / \mathrm{L},{ }^{\mathrm{c}} 5 \mathrm{mg} / \mathrm{L}$, and ${ }^{\mathrm{d}} 50 \mathrm{mg} / \mathrm{L}$ groups. $* P<0.05, * * P<0.01, * * * P<0.001,{ }^{\dagger} P=0.05$ 